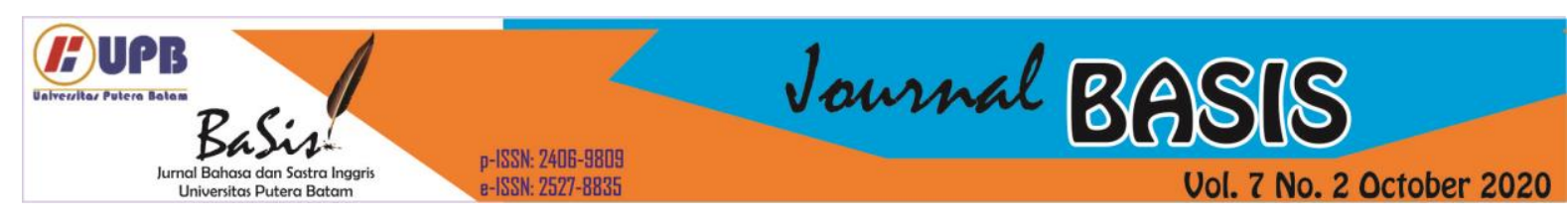

\title{
ANALYSIS OF THE CONTENT OF EXERCISE SEVENTH GRADE ENGLISH TEXTBOOK
}

\author{
Sjafty Nursitti NP Maili ${ }^{1}$ \\ University of Indraprasta PGRI Jakarta \\ sjaftym@gmail.com \\ Endang Sondari ${ }^{2}$ \\ University of Indraprasta PGRI Jakarta \\ endang-sondari@yahoo.com
}

\begin{abstract}
The aim of this study was to analyze the content of exercise in the English textbook appropriate with the criteria a good exercise or activity in the English textbook purposed by expert theory. This study is a qualitative research which the data was obtained with observation and documentation; First, Interview, researcher asked English teacher to answer the questions; Second, documentation, data was taken based on the main English textbook used SMP Muhammadiyah Cawang 4 Jakarta Timur namely Buku Bahasa Inggris untuk SMP/MTS Kelas VII by Erlina, S and Muhammad, $\mathrm{H}$ published Mediatama. In the English textbook there were 24 exercises. The result of this research shows that the exercises of this book provided from 24 exercises which were six exercises without new vocabulary students to communicate and five exercises do not incorporate by pair/group work, so the exercise do not meet criteria with a good exercise in the English textbook, but the English teacher always give the supplementary material that taken from other media sources
\end{abstract}

Key words: English textbook, exercise, textbook evaluation

\section{INTRODUCTION}

Language teaching cannot be separated from textbook, as textbooks play an important a role for teachers and students. For teachers, especially English teachers, English textbook as a guide to assist English teacher in conducting learning process activities. For students, English textbooks make them gain the knowledge and information. According to Nunan, D (1991) stated textbook is a tool and the teacher must know not only how to use it, but how to make it useful. In other words, English textbook are actually very important to bring students to understand the materials provided by the teachers, therefore the English teacher should really understands how important English textbooks are. Textbooks are also the teacher's instruction in providing material in the classroom. Teachers cannot conduct teaching and learning activities without a textbook instruction, so textbooks are really an important thing to teachers and students

The English textbook used SMP Muhammadiyah 4 Jakarta namely Bahasa Inggris Untuk SMP/MTS Kelas VII by Erlina Setijani \& Muhammad Haman Abdurrohman, Published 
Mediatama. There are three reasons to analyze content of exercise or activity in this English textbook, First, the English textbook has already followed 2013 curriculum, the English textbook is important of component of learning activity, hope the textbook was used in the classroom should involving the learning process, educational evaluation system as well as competencies that match expectation. Second, the English textbook presented a high order thinking (HOT); the government suggests that the materials were given to students is to enable students to identify problems, analyze and solve problems. Third, Lack of research on an exercises or activity in English textbook, because many studies discuss textbook but research on analysis of exercises or the activity still lacking.

Evaluation is a way to done for selecting the materials because in the content of the English textbooks so many chapters and each chapter consist of four exercises or activity. So the textbook needs to evaluate. According to Fredrikson \& Olsson, 2006,p.7 in Rizky stated that many English textbooks are available out there; selecting the most suitable one is the problem. In other words, selecting is the way out to solve to the problem about the textbook. Textbook evaluation proposed of expert theory according to Rachmawati, L(2018) there are four criteria a good the textbook as first objective, learning., exercise, vocabulary, in this study researcher focuse on the exercise or activity in the English textbook using SMP Muhammadiyah Jakarta Timur

Talking about the textbooks, there are many researchers that have conducted of English textbook, they are first, Akbar, R.(2016) his analysis of the research was appropriateness of content.
The content is divided into three aspects, including relevance of materials with competency standards and basic competencies, materials accuracy, and supporting learning materials. The instrument used for this study is a checklist adapted from Badan Standard Nasional Pendidikan (2014) framework for textbook evaluation. The result of the analysis showed that both textbooks are appropriate in terms of content based on BSNP framework for textbook evaluation.

Second, Rachmawati,L(2018) her analysis of the study of English textbook and divided the objectives, materials, exercises, vocabulary. The result of her study shows that objectives of the lessons in the textbook meet the criteria og a good English textbook.

\section{LITERATURE REVIEW}

2.1.Textbook

Textbook has a role important to students and teachers in the process of activities in the classroom. Teachers are the one who gives the materials to students and teachers have a great ability to choose the textbook that used in the learning activity process, so that textbook became meaningful to teachers and students. In addition, textbooks control teacher, students as well as the dynamic of the classroom ( Saed,N, Hadi,H \& Rezvan, M : 2013)

There are many definitions about textbook. According to Tok (2010) in Reza (2016) stated that a textbook must be of an acceptable quality, useful, and appropriate for the context and people with whom they are being used if a teacher is going to use it, in language teaching. According to Cunningsworth (1995) argues that textbooks are an effective resource for self-directed learning, an effective source for 
presentational material, a source of ideal and activities, a references source for students, a syllabus where they reflect pre- determined learning objectives, and support for less experienced teachers who are yet to gain confidence. In addition, Nurhaeda, G, $\operatorname{dkk}(2019)$ a textbook is defined as a book that teachers a particular subject and that is used especially in schools and colleges. Celcer-Murcia (1977) argues that information on textbook is so helpful that becomes the teachers' duty to choose the textbook.

Based on the definition above the researcher concluded that textbook is a book that accommodation about learning activities, objective of the activities and effective for presentation materials including exercises or activity. Nunan, D (1988:98) in Meita, F (2013) stated that materials are, in fact an essential element within the curriculum, and do more than simply lubricate the whole of learning. According to Cunningsworth (1995) stated the textbook have multiple roles in ELT and can serve as:1) a resource for presentation material;2) A source of activities for learner practice and communicative interaction;3) A source of simulation and ideas for classroom language activities; 4) a reference source for learners on grammar.vocabulary,

pronunciation;ets;5) a syllabus where they reflect learning objectives which have already been determined; 6) a resource for self-directed learning or self-access work; 7) a support for les experieces teachers who have already been determine;8)a resource for selfdirected learning or self-directed learning or self-access work. 9) a support four less exprien teachers who have you to gain in confidence. Rachmawati, L 92018) devided four component in evaluation textbook; 1.) Objective of the lesson; 2) facilitate teaching learning process;3) exercise;4) vocabulary.

\subsection{Evaluation Exercise Textbook}

According to Wong stated C\&A guide has listed the five following features in relation what a task should constitute:1), The tasks have a purpose;2) The tasks have a context which the purpose for using language emerges;3) The tasks can involve learners in a mode of thinking and doing;4) The tasks are purposeful activities in which the carrying out of a task should lead towards a product;5) The tasks require the learners to draw upon their framework of knowledge and skills and should also enable them to strengthen or extend this.In addition, Wong (2010) that in the task activities, most questions are open-ended questions which can effectively arouse learning interest and also stimulate learners imagination and creativity. There is generally a good balance of pre, while, and post learning tasks and these are effective in engaging learners into active class participation. Teachers should see textbook evaluation as part of their professional development (Mukundan \& Ahour 2010) so that they can have a better understanding of the role textbooks play in the classroom (Richards 1998). Rachmawati, L(2018) stated the exercise should fulfilled three aspect below to be categorized as a good textbook from exercise analysis;1.) Require students to use new vocabulary;2) The exercise promote critical thinking of the text; 3) The exercises incorporate individual, pair and group work. 


\section{RESEARCH METHOD}

3.1. Time And Location Research

This study has been conducted in March until July 2020; researcher took the data after getting the letters from LPPM UNINDRA. It was started beginning of April because the letters was accepted at the end of April. This study has been conducted at SMP Muhammadiyah Cawang Jakarta Timur.

\subsection{Method Of Research}

This research used Qualitative research which the descriptive method used. In the descriptive researchers describe the phenomenon of the study, and identify, make the references, then doing the conclusion

3.3. Technique Data Collection

There were some steps done of researchers as follow;

1. Observation

2. Documentation

\subsection{Research Instrument}

The instrument that researchers used is taken from the English textbook namely Buku Bahasa Inggris by publish Mediatama. The evaluation of this study using by EFL criteria of a good exercise in English textbook, First, Requiring students use a new vocabulary to communicate; Second, Promoting critical thinking; Third, Incorporating students individual in a pair and groups work

\subsection{Technique Of Data Analysis}

The technique of data analysis, there are some steps we done as follow:

1. Prepare the data

2. Tabulation

3. Analysis

4. Conclusion

\section{RESULT AND DISCUSSION}

The research described about the exercise/activity in the English textbook namely BAHASA INGGRIS UNTUK SMP/MTS KELAS VII by Erlina Setijani\&Muhammad Haman Abdurrohman, Published MEDIATAMA as main book used SMP MUHAMMADIYAH 4 Jakarta Timur. It consists of seven units and 25 activities which are unit 1 consist of 3 activities: units 2 consist of 4 activities; unit 5 consists of 4 activities; unit 6 consists of 4 activities; unit 7 consists of 3 activities.. After finding the data, we continue to described of analysis by the criteria of a good exercises of materials purposed by expert and developed by Rachmawati, L (2018) as followed; First, requiring students to use a new vocabulary to communicate; Second, Promoting a high thinking; Last, Incorporating individual in a pair and groups

\section{RESULT}

There are 24 exercises/activities presented in this English textbook. Result was seen in the tables below:

Table 4.1. Exercise/Activity 1

\begin{tabular}{llll}
\hline $\begin{array}{l}\text { Exercise/ } \\
\text { Activity }\end{array}$ & $\begin{array}{l}\text { Requiring } \\
\text { students to } \\
\text { use a new } \\
\text { vocabulary }\end{array}$ & $\begin{array}{l}\text { Promoting } \\
\text { critical } \\
\text { thinking } \\
\text { the text }\end{array}$ \\
1.1 & & & $\begin{array}{l}\text { Incorporating } \\
\text { by individual } \\
\text { pair and } \\
\text { group works }\end{array}$ \\
1.2 & & $\checkmark$ &
\end{tabular}

1. Requiring students to use a new vocabulary to commnunicate

Exercise/activity 1.2:

Sania meets Twain, her new classmate, outside the class

Sania: I enjoyed talking to you

Twain: I enjoyed talking to you too

Sania: we should 
Mom: I think that would be nice

Sania: Is there anything you would like to do next time

Twain:

Sania:

Twain; I'll talk to you later.(p.10)

Find and underline the parting expressions in the dialogue

2. Promoting critical thinking of the text

Exercise/Activity 1.3:

Write a simple dialogue containing parting expression with your friend (p.10)

3. Incorporating by individual pair and group works

Exercise/Activity 1.4:

Practice the conversation. Ask your seatmate to practice the conversation with you. (p.18)

Table 4.2. Exercise/Activity 2

\begin{tabular}{llll}
\hline $\begin{array}{l}\text { Exercise/ } \\
\text { Activity }\end{array}$ & $\begin{array}{l}\text { Requiring } \\
\text { students to } \\
\text { use a new } \\
\text { vocabulary }\end{array}$ & $\begin{array}{l}\text { Promoting } \\
\text { critical } \\
\text { thinking } \\
\text { the text }\end{array}$ \\
2.1 & - & $\checkmark$ & $\begin{array}{l}\text { Incorporating by } \\
\text { individual pair } \\
\text { and group works }\end{array}$ \\
2.2 & $\checkmark$ & $\checkmark$ & $\checkmark$ \\
2.3 & $\checkmark$ & $\checkmark$ & $\checkmark$ \\
2.4 & $\boldsymbol{V}$ & $\checkmark$ & - \\
\hline
\end{tabular}

Based on table 4.2 in activity 2.1 the researcher gave examples below

1. Requiring students to use a new vocabulary to communicate

Exercise/Activity 2.2:

If there is any word you don't understand, mark them, and search the meaning in dictionary

2. Promoting critical thinking of the text Exercise /Activity 2.3:

Write a short text about your new classmates. Use subject pronoun and object pronoun appropriately.
3. Incorporating by individual pair and group works

Exercise/Activity 2.4:

To check your sentence, try to present your work in front of the class.

Table 4.3. Exercise/Activity 3

\begin{tabular}{llll}
\hline Exercise/ & $\begin{array}{l}\text { Requiring } \\
\text { Activity } \\
\text { students to } \\
\text { use a new } \\
\text { vocabulary }\end{array}$ & $\begin{array}{l}\text { Promoting } \\
\text { critical } \\
\text { thinking of } \\
\text { the text }\end{array}$ & $\begin{array}{l}\text { Incorporating } \\
\text { by individual } \\
\text { pair and } \\
\text { group works }\end{array}$ \\
3.1 & & $\checkmark$ & $\checkmark$ \\
3.2 & & $\checkmark$ & $\checkmark$ \\
3.3 & $\sim$ & $\checkmark$ & $\checkmark$ \\
\hline
\end{tabular}

1. Requiring students to use a new vocabulary

Exercise/Activity 3.1:

Mr Farkhan is talking to Dian in the class

Mr.Farkhan : Do you have any brother and sister Dian?

Dian : I have two brothers. I am (3rd) .......children of my family.

Mr Farkhan :So how many family members are there in your family?

Dian : There are

(5).............including me(p.62)

2. Promoting critical thinking of the text

Exercise/Activity 3.2:

Write a short dialogue about asking and telling the birthday of your classmates. Write the date and use ordinal number appropriately. (p.66)

3. Incorporating by individual pair and group works

Exercise/Activity 3.3: Compare and check the answer with your seatmate (p.71)

Table 4.4. Exercise/Activity 4

\begin{tabular}{|c|c|c|c|}
\hline $\begin{array}{l}\text { Exercise/ } \\
\text { Activity }\end{array}$ & $\begin{array}{l}\text { Requiring } \\
\text { students to } \\
\text { use a new } \\
\text { vocabulary }\end{array}$ & $\begin{array}{l}\text { Promoting } \\
\text { critical } \\
\text { thinking of } \\
\text { the text }\end{array}$ & $\begin{array}{l}\text { Incorporating } \\
\text { by individual } \\
\text { pair and group } \\
\text { works }\end{array}$ \\
\hline 4.1 & $\checkmark$ & $\boldsymbol{V}$ & $\checkmark$ \\
\hline 4.2 & - & $\checkmark$ & $\nu$ \\
\hline
\end{tabular}




\begin{tabular}{llll}
\hline 4.3 & $\boldsymbol{V}$ & $\boldsymbol{V}$ & - \\
4.4 & - & $\boldsymbol{V}$ & $\boldsymbol{V}$ \\
4.5 & $\boldsymbol{V}$ & $\boldsymbol{V}$ & $\boldsymbol{V}$ \\
\hline
\end{tabular}

1. Requiring students to use a new vocabulary

Exercise/Activity 4.1:

Complete the sentences in the blanks spaces with plural or singular nouns

a. There are some.....(men/man) who wait for the bus

b. It's not difficult to grow a mango......(tree/trees) as long as you give it plenty of water

2. Promoting critical thinking of the text

Exercise/Activity 4.2:

Write a short dialogue about your classroom. Use article appropriately (p.91)

3. Incorporating by individual pair and group works

Exercise /Activity 4.4: Practice the dialogue with your seatmate (p.99)

Table 4.5. Exercise/Activity 5

\begin{tabular}{llll}
\hline Exercise/ & $\begin{array}{l}\text { Requiring } \\
\text { Activity } \\
\text { students to } \\
\text { use a new } \\
\text { vocabulary }\end{array}$ & $\begin{array}{l}\text { Promoting } \\
\text { critical } \\
\text { thinking of } \\
\text { the text }\end{array}$ & $\begin{array}{l}\text { Incorporating } \\
\text { by individual } \\
\text { pair and } \\
\text { group works }\end{array}$ \\
5.1 & $\checkmark$ & $\checkmark$ & $\checkmark$ \\
5.2 & - & $\checkmark$ & $\checkmark$ \\
5.3 & $\checkmark$ & $\checkmark$ & $\checkmark$ \\
\hline
\end{tabular}

1. Requiring students to use a new vocabulary

Exercise/Activity 5.3:

After you find adverb of time, write the meaning of the adverb ( $p$ 130)

2. Promoting critical thinking of the text Exercise/Activity 5.3:

Write a short dialogue using adverb of time in a simple present tense. Write about your weekends activities.(130)
3. Incorporating by individual pair and group works

Exercise/Activity 5.2: Ask your seatmates to practice the dialogue with you (p.124)

Table 4.6. Exercise/Activity 6

\begin{tabular}{llll}
\hline $\begin{array}{l}\text { Exercise/ } \\
\text { Activity }\end{array}$ & $\begin{array}{l}\text { Requiring } \\
\text { students to } \\
\text { use a new } \\
\text { vocabulary }\end{array}$ & $\begin{array}{l}\text { Promoting } \\
\text { critical } \\
\text { thinking of } \\
\text { the text }\end{array}$ & $\begin{array}{l}\text { Incorporating } \\
\text { by individual } \\
\text { pair and } \\
\text { group works }\end{array}$ \\
6.1 & - & $\checkmark$ & - \\
6.2 & $\checkmark$ & $\checkmark$ & - \\
6.3 & $\checkmark$ & $\checkmark$ & $\checkmark$ \\
6.4 & $\checkmark$ & $\checkmark$ & \\
\hline
\end{tabular}

1 Requiring students to use a new vocabulary

Exercise /Activity 6.2:

If there is any word you don't understand mark them and search their meaning in your dictionary. (p. 150)

2.Promoting critical thinking of the text

Exercise/Activity 6.1:

Retell the story using own words based on your important points the text above. (p.144)

3. Incorporating by individual pair and group works

Exercise/Activity 6.4:

Discuss the character of language feature between of descriptive text. (p.157)

Table 4.7. Exercise/Activity 7

\begin{tabular}{llll}
\hline $\begin{array}{l}\text { Exercise/ } \\
\text { Activity }\end{array}$ & $\begin{array}{l}\text { Requiring } \\
\text { students to } \\
\text { use a new } \\
\text { vocabulary }\end{array}$ & $\begin{array}{l}\text { Promoting } \\
\text { critical } \\
\text { thinking } \\
\text { the text }\end{array}$ & $\begin{array}{l}\text { Incorporating } \\
\text { by individual } \\
\text { pair and } \\
\text { group works }\end{array}$ \\
7.1 & $\checkmark$ & $\checkmark$ & $\checkmark$ \\
7.2 & $\checkmark$ & $\checkmark$ & - \\
7.3 & - & $\checkmark$ & $\checkmark$ \\
\hline
\end{tabular}

1. Requiring students to use a new vocabulary to communicate

Exercise/Activity 7.2:

To help you analyses the moral value of the song above, find the meaning of words below: 
a. Fame:

b. Luck

2. Promoting critical thinking of the text Exercise /Activity 7.1:

The song above is divided into some parts. Analyze and write the parts of the song's lyric above correctly

3. Incorporating by individual pair and group works

Exercise/Activity 7.3:

Simulate your groups' discussion in front of the class. (p 179)

\section{DISCUSSION}

Based on the findings the data, we discussed using the criteria of good exercises of materials purposed by expert. In this study resulted three important points: 1.) The requiring students to use a new vocabulary to communicate; 2) Promoting critical thinking of the text, 3) Incorporating by individual pair, and group work

1. Requiring students to use a new vocabulary to communicate

In the English textbook for Junior High School in proposing the first exercise there is a dialogue accompanied by words that must be filled in by the students, after filling in then the students are asked to communicate but there are six exercises where there is no dialogue so that the exercises still do not meet the criteria for a good exercise English book and suggested curriculum 2013 as follow; a) observing; b) asking) information collected; c) associating; d) communicating (Hasbullah, M:2015, p. 138), there are some exercises or activity missing of the vocabulary, so the exercises of English textbook still not a fulfill a good exercises of the English textbook.
2. Promoting critical thinking of the text

There are many exercises of reading provide students motivation because the material are interesting. According to Cunningsworth (1995) reading passages and associated activities to suitable for the student's level and interest.

Varied reading task provide students with motivation, for an example activity 7.3 the title is understanding and distinguishing different types of song, type of activity is a group task. In this activity the students are asked to make a group consist of 4-6 members to do the assignment and then presented reading text its topic "Number One For Me: by Maher Zein", All of the exercises in English textbook fulfill this component, therefore the exercises meet the criteria of good exercises English textbook.

3. Incorporating by individual pair, and group work

The exercises are interested because there are so many pictures, and the task described from simple to complicate, but there are some exercises that do not support individual pair and group work, therefore this component does not meet the criteria for a good exercises purposes to Rachmawati, L (2011)

\section{CONCLUSION}

Based on the analysis data in the English accordance of expert theory so that the exercises or activity English textbook is suitable to use for first grade of junior high school especially SMP Muhammadiyah 4 but need to considering that for first component is requiring a new vocabulary to communicate still lack a vocabulary and for third components is incorporating by pair group and group work some exercises or activity not provided pai 
group and group work but these are solved because English teachers gave the other materials that found from other sources.

\section{REFERENCE}

Akbar, R (2016). An Analysis of Selected Eleventh Grade English textbook. Journal of English and Education 4(!), 119 -126, http; scholar.google.com/scholar?hl+en \&as-sdt=)\&25

Ansary,H\&Babai i(2002) Universal Characteristics of EFL Textbook: A step Towards Systematic Textbook Evaluation. The internet TESL Journal,8(2),1-9. Retrieved from

https://itesLj.org/Articles/AnsarryTextbook.Shiraz University(Shiraz,Iran)

Cunningsworth, A (1995).Choosing Your

Coursebook.Oxford;Macmillan Helneman.

Hayati, W\&Astuti, p.2019). Content analysis of Students Book When English rings a Bell (Revised Edition) for Grade VII of Junior High School. Journal of English Language Teaching. English Department, Faculty of Language and Arts, Universitas Negeri Semarang, Indonesia. Http ;/ journal.unnes.ac.id/sjn/index.php/e lt
Hasbullah, H (2015). Kebijakan Pendidikan. PT Raja Grafindo Persada Jakarta.

Mukundan, Reza \& Vahid (2011). Developing An Analysis Language Textbook Evaluation Checklist. Contemporary Issues in Education Research, $4\left(^{\wedge}\right), 21-27$.

Meita, F (2013). A Textbook Analysis of when English Rings the Bell, an Textbook for Seventh grade of junior High School. Thesis. English Language education. Language and Arts Faculty Yogyakarta State University.

Recount Textt through Wikis Media. http:// ejournal.unp.ac.id/index, php/jelt/article/view/11620 teaching journal.

Rachmawati,L(2018).A Content Analysis Of The English Textbook Primary English As Second Language. Thesis.Sunan Ampel State Islamic University Surabaya.

Saed,N, Hadi,H \& Rezvan, M (2013). A Critical look at textbook evaluation; ACase Study of evaluating an ESP Course- book; English for international tourism.https;//scholar.google.co.id /scholar?q=cunningsworth+textbo $\mathrm{ok}=$ evaluation $=$ checklist

Wong,L 2011. Textbook evaluation; a framework for evaluating the fitness of the Hongkong new secondary school nss curriculum. Thesis, Department of English city University of Hong kong. 